\title{
Problematyka polskiej leksyki ogólnej w świetle Nisbettowskiej koncepcji geograficzno-kulturowych uwarunkowań myślenia
}

\section{The issue of Polish vocabulary from the perspective of the Nisbett's concept of geo-cultural determinants of human thinking}

\author{
Ewa Rudnicka
}

\begin{abstract}
INSTYTUT BADAŃ INTERDYSCYPLINARNYCH „ARTES LIBERALES”, UNIWERSYTET WARSZAWSKI, UL. NOWY ŚWIAT 69, O0-046 WARSZAWA
\end{abstract}

$$
\text { ewa.rudnicka@uw.edu.pl }
$$

\begin{abstract}
The article deals with Nisbett's conception of geography of thought and its linguistic confirmations. Basing on Nisbett's theses the problem of Polish mentality and language is concerned. That is why lexis and some others linguistic aspects are analysed in purpose to find the answer for the question if Polish thought is more like Asian or more like Western. The main focus for research is the grammatical structure of Polish lexis, the percentage of polysemous words in Polish language and the generic usage of Polish nouns.
\end{abstract}

Keywords: system leksykalny polszczyzny, struktura gramatyczna polskiej leksyki, polisemiczność polskiego słownictwa, język a myślenie, umysłowość amerykańsko-zachodnioeuropejska, umysłowość dalekowschodnia, koncepcja R. E. Nisbetta.

\section{Język i myślenie}

Język a myślenie - to kwestia właściwie nieustannie intrygująca badaczy (w szczególności z kręgów humanistycznych), a wzrost popularności kierunków kognitywnych przyczynił się $\mathrm{w}$ ostatnich latach do bardzo żywego ponownie zainteresowania się tą tematyką i intensywnego zgłębiania problemu wzajemnych relacji tych dwóch jakże istotnych dla człowieka fenomenów.

Aksjomatem jest twierdzenie, że język jest faktem społecznym - językoznawcy doszli do takiego wniosku już dawno i co do tego nie ma wśród badaczy sporu. 
Powszechnie przyjmuje się także, że język i myślenie wzajemnie na siebie oddziaływają i wzajemnie się kształtują (acz dyskusyjna jest kwestia dominacji w tej relacji jednego bądź drugiego zjawiska - czy bardziej język wpływa na sposób percepcji i myślenia, czy odwrotnie: sposób myślenia wpływa na wyodrębnianie się w systemie języka takich lub innych elementów czy kategorii). Z tych dwóch założeń nie można jednak wyciągnąć prostego i jednoznacznego wniosku, iż myślenie (a w tym percepcja i procesy poznawcze) - podobnie jak język również jest faktem społecznym oraz, co za tym idzie, że myślenie jest uwarunkowane kulturowo i w jakimś sensie - z przyjęciem pewnych uogólnień również geograficznie. Wprawdzie psychologowie badający procesy poznawcze jeszcze do niedawna zakładali uniwersalny charakter ludzkiego myślenia, jednak badacze z innych dyscyplin wskazywali na odmienność systemów myślenia ludzi z różnych kręgów kulturowych (Nisbett 2011:13).

Kwestii tej poświęcił swoje rozważania i badania empiryczne amerykański psycholog społeczny Richard Nisbett, który wyniki studiów zawarł w studium zatytułowanym „Geografia myślenia” z podtytułem „Dlaczego ludzie Wschodu i Zachodu myślą inaczej". Warto zwrócić uwagę już na brzmienie tytułu. Polski przekład autorstwa Ewy Wojtych wydany po raz pierwszy w roku $2009 \mathrm{w}$ sopockim wydawnictwie „Smak Słowa” ma bowiem w stosunku do oryginału charakter dużo bardziej - rzec by można - marketingowy. Nisbett opublikował swoją książkę w roku 2003 nadawszy jej tytuł „The Geography of Thought. How Asians and Westerners Think Differntly... and Why". Istotne jest więc, by mieć świadomość, o czyim myśleniu tak naprawdę autor pisze ${ }^{1}$, ponieważ zarówno określenia „ludzie Wschodu”, „ludzie Zachodu”, jak i „Asians” oraz „Westerners” są relatywnie za szerokie zakresowo, jeśli przyjrzeć się narodowościom badanych grup społecznych.

W niniejszym artykule za cel stawia się konfrontację twierdzeń amerykańskiego badacza $\mathrm{z}$ obserwacjami polskiego materiału językowego (w szczególności - leksykalnego). Stawiane zaś pytanie badawcze brzmi: czy - przy założeniu słuszności diagnozy Nisbetta dotyczącej zespołu cech charakteryzujących kulturę wschodnioazjatycką i amerykańskozachodnioeuropejską - można na podstawie analiz językowych dotyczących zwłaszcza poziomu leksykalnego powiedzieć o polskiej wspólnocie komunikacyjnej, że w swoim myśleniu jest bliższa Zachodowi lub Dalekiemu Wschodowi ${ }^{2}$.

\footnotetext{
${ }^{1}$ Badaniami, jakie prowadził Nisbett bądź jego współpracownicy i koledzy po fachu, objęci byli przede wszystkim Amerykanie, Kanadyjczycy, Brytyjczycy i, w mniejszym stopniu, Skandynawowie (Szwedzi), Holendrzy, Belgowie, Niemcy, Francuzi, Włosi, Australijczycy, a z drugiej strony - Chińczycy, Japończycy, Koreańczycy oraz w bardziej ograniczonym zakresie Singapurczycy, Tajwańczycy, mieszkańcy Hongkongu. Przy czym - co znamienne - Nisbett stwierdza, że kraje śródziemnomorskie, a także Belgia i Niemcy, znajdują się na tej skali mentalności pomiędzy krajami Wschodu a krajami, na których odcisnęła piętno protestancka kultura anglosaska (Nisbett 2011:64).

${ }^{2} \mathrm{~W}$ polskim tłumaczeniu książki Nisbetta stosowane są umowne określenia „Wschód” i „Zachód” (oraz odpowiednie określenia przymiotnikowe), mimo że jest to oczywiście znaczne uproszczenie. W niniejszym tekście chętniej będziemy sięgać po określenia bardziej precyzyjne, niemniej całkiem nie będziemy się odżegnywać od tych nazw umownych.
} 


\section{Zróżnicowanie systemów myślenia ludzi z różnych obszarów świata}

Intencją Nisbetta było wykazanie, że istnieje coś takiego, co można ogólnie nazwać geografią myślenia, czyli uwarunkowanie sposobu rozumowania, percepcji i przebiegu procesów poznawczych tym, w jakim miejscu i w jakim społeczeństwie było się urodzonym i wychowywanym. Sladów geografii myślenia Nisbett doszukuje się $w$ różnych przejawach działalności ludzkiej. Znajduje oczywiście ich odzwierciedlenie także w języku (co jest zgodne zarówno $\mathrm{z}$ logicznym wnioskowaniem na temat natury języka i myślenia, jak i z empirią). $\mathrm{Na}$ przykłady tego rodzaju odzwierciedleń powołuje się autor, dowodząc konkretnych różnic w sposobach myślenia oraz cechach mentalności mieszkańców Dalekiego Wschodu (Azji Wschodniej) i mieszkańców świata zachodniego (w założeniu obejmującego Amerykę Północną i Europę Zachodnią).

Najważniejsze cechy poszczególnych społeczności, jakie wyróżnia badacz, można w skrócie ująć kontrastywnie w formie tabeli (tabela 1.):

Tabela 1. Cechy charakterystyczne społeczności zachodnich i dalekowschodnich.

\begin{tabular}{|c|c|}
\hline $\begin{array}{c}\text { Mieszkańcy świata zachodniego } \\
\text { (Ameryki Północnej i Europy } \\
\text { Zachodniej) }\end{array}$ & $\begin{array}{c}\text { Mieszkańcy Dalekiego Wschodu } \\
\text { (wschodniej Azji) }\end{array}$ \\
\hline $\begin{array}{l}\text { JEDNOSTKA I SPOŁECZNOŚĆ } \\
\text { 1. niezależność, indywidualizm } \\
\text { jednostki, dążenie do osobistych } \\
\text { celów }\end{array}$ & $\begin{array}{l}\text { JEDNOSTKA I SPOŁECZNOŚĆ } \\
\text { 1. współzależność, wspólnotowość } \\
\text { (jednostka to członek różnych } \\
\text { wspólnot), przedmiotem troski są } \\
\text { cele grupy albo skoordynowanie } \\
\text { działania, }\end{array}$ \\
\hline $\begin{array}{l}\text { 2. pomoc rodziców w przygotowaniu } \\
\text { się dzieci do życia w świecie, w } \\
\text { którym inni będą od nich oczekiwać } \\
\text { niezależności działania }\end{array}$ & $\begin{array}{l}\text { 2. pomoc rodziców w przygotowaniu } \\
\text { się dzieci do przewidywania reakcji } \\
\text { ludzi, z którymi będą musieli w } \\
\text { przyszłości zgodnie działać }\end{array}$ \\
\hline 3. egalitaryzm i uniwersalizm & $\begin{array}{l}\text { 3. brak uniwersalizmu, zróżnicowanie } \\
\text { praw i obowiązków, równe } \\
\text { traktowanie wszystkich ludzi nie jest } \\
\text { konieczne ani nawet pożądane }\end{array}$ \\
\hline $\begin{array}{l}\text { 4. pojmowanie } \\
\text { wyindywidualizowanego JA jako } \\
\text { sumy cech przynależnych jednostce }\end{array}$ & $\begin{array}{l}\text { 4. pojmowanie JA jako sumy ról } \\
\text { społecznych pełnionych przez } \\
\text { jednostkę }\end{array}$ \\
\hline 5. poczucie osobistej sprawczości & 5. poczucie sprawczości zbiorowej \\
\hline $\begin{array}{l}\text { 6. zakładanie niezmiennej, } \\
\text { niepowtarzalnej tożsamości } \\
\text { jednostki w różnych okolicznościach } \\
\text { społecznych }\end{array}$ & $\begin{array}{l}\text { 6. zakładanie zmienności tożsamości w } \\
\text { zależności od aktualnie pełnionych } \\
\text { ról i aktualnych okoliczności } \\
\text { społecznych }\end{array}$ \\
\hline
\end{tabular}


ŚWIAT

7. koncentracja na obiektach

8. skłonność do klasyfikowania obiektów wg atrybutów, cech wspólnych, ,paradygmatycznych”

9. wyimkowe postrzeganie świata (postrzeganie obiektów w izolacji), świat to zbiór odrębnych obiektów

10. postrzeganie świata poprzez to, co w nim stałe

ROZUMOWANIE

11. racjonalność, precyzyjne zasady do systemowego opisu obiektów i wyjaśniania zjawisk

12. rozumowanie logiczne

13. przekonanie o możliwości sprawowania kontroli nad otoczeniem

14. w sytuacji konfliktowej opowiadanie się za jednym ze stanowisk

15. rzeczywistość rządzi się pewnymi niezmiennymi prawami, więc pojęcia są stałe i obiektywne, świat jest spójny i dający się poklasyfikować na kategorie

16. obowiązuje prawo tożsamości i niesprzeczności (rzecz jest stale tą samą rzeczą, coś nie może być jednocześnie czymś i odwrotnością tego czegoś)

\section{ŚWIAT}

7. koncentracja na środowisku i relacjach między obiektem a innymi obiektami lub środowiskiem

8. brak potrzeby klasyfikowania obiektów, przy skłonności do grupowania ich wg powiązania, wzajemnego wpływu na siebie, związków ,syntagmatycznych”

9. holistyczne postrzeganie świata, świat to masa substancji

10. postrzeganie świata poprzez to, co w nim zmienne

\section{ROZUMOWANIE}

11. kontekstualność, intuicyjność, brak reguł ze względu na to, że świat jest zbyt skomplikowany (zdarzenia wzajemnie od siebie zależą, obiekty można rozpatrywać tylko w określonym kontekście)

12. rozumowanie dialektyczne

13. brak przekonania o możliwości sprawowania kontroli nad otoczeniem

14. w sytuacji konfliktowej poszukiwanie kompromisu (drogi środka)

15. ponieważ rzeczywistość jest dynamiczna i zmienna, więc pojęcia, które ją odzwierciedlaja, są raczej płynne i subiektywne niż stałe $i$ obiektywne

16. obowiązuje zasada sprzeczności, we wszystkim tkwią przeciwieństwa (elementy stare $\mathrm{i}$ nowe, dobre i złe, silne i słabe), które się wzajemnie uzupełniają

\section{Językowe potwierdzenia zróżnicowania systemów myślenia}

Język nie stanowi dla Nisbetta podstawowego materiału dowodowego, lecz chętnie sięga on po przykłady językowe, w których szuka dodatkowego potwierdzenia wyników eksperymentów psychologicznych dotyczących społecznych i psychologicznych różnic między światem dalekowschodnim i 
amerykańsko- zachodnioeuropejskim. Opisywane przez autora badania, czy raczej obserwacje językowe, wiążą się $\mathrm{z}$ takimi sprawami jak: werbalizacja indywidualizmu $i$ tekstowe przejawy mentalności indywidualistycznej, przypisywanie odpowiedzialności za skuteczność komunikacyjną, konstrukcja logiczno-gramatyczna przysłów, werbalizacja sprawczości, modele uczenia się języka, w tym zwłaszcza sposoby jego opanowywania przez dzieci, a także z zagadnieniami dotyczącymi wybranych cech gramatycznych (np. szyku wyrazów w zdaniu, udziału w słownictwie rzeczowników odprzymiotnikowych nazywających atrybuty) i pragmatycznych (np. użycia zaimków osobowych JA) poszczególnych języków. Osobną uwagę poświęca też badacz poziomowi leksykalnemu, nie prowadzi jednak żadnych wnikliwych analiz ani badań statystycznych czy to $\mathrm{w}$ odniesieniu do całości systemu, czy też do jego poszczególnych poziomów.

Wprawdzie zasadniczym tematem niniejszego artykułu są przejawy ,geografii myślenia" w sferze leksykalnej języka, pokrótce jednak warto wspomnieć i inne kwestie poruszane przez amerykańskiego psychologa, a wzmiankowane powyżej.

Nisbett zwraca na przykład uwagę na to, że Chińczycy nie znają słowa „indywidualizm”, zaś najbliższe mu znaczeniowo określenie w języku chińskim to „samolubstwo”, a z kolei chińskie słowo ,jên” 'życzliwość' - oznacza dwoje ludzi. Japończycy natomiast rzadko - jak podaje - używają zaimka ,ja" o charakterze ogólnym, czyli ,ja” niezależnego od sytuacji, w której się ktoś znajduje (ze wszystkimi cechami, celami, zdolnościami i preferencjami). Zamiast tego w zależności od rozmówcy i okoliczności stosują oni wiele różnych słów znaczących tyle co 'ja', co jest wyrazem panującego na Dalekim Wschodzie przekonania, że człowiek nie jest tą samą osobą w kontaktach z różnymi ludźmi (Nisbett 2011:51-52).

W polszczyźnie próżno szukać analogicznych przykładów, mamy zarówno „indywidualizm” (choć nb. zapożyczony), jak i „samolubstwo” (całkowicie rodzime). Przy okazji jednak warto być może zwrócić uwagę na funkcjonowanie w polszczyźnie produktywnych także współcześnie przedrostków „samo-" i „współ-”. Pierwszy przedrostek cechuje się dwoistością funkcji - po pierwsze, wskazuje na wykonywanie czegoś albo na funkcjonowanie kogoś lub czegoś bez jakiejkolwiek pomocy (np. „samoczynny”, „samorzutny”, „samowyzwalacz”, „samozapłon”), po drugie, określa, że działanie jest skierowane na samego wykonawcę czynności (np. „samokrytyka”, „samolubstwo”, „samostanowienie”), drugi zaś przedrostek jest jednoznaczny i stanowi człon wyrazów złożonych, wskazujących na jakąś wspólną cechę, na wspólne działanie czy wspólne występowanie w jakimś charakterze (np. „współbiesiadnik”, „współpraca”, „współodpowiedzialność”, „współwinny”, ,współrządzić”), przy czym wyrazów z członem ,samo-" jest w słownikach średnio dwukrotnie więcej niż tych z członem „Współ-”.

Poza tym warto też wspomnieć zapomniane już współcześnie konstrukcje przysłówkowo-liczebnikowe i przymiotnikowo-liczebnikowe typu: „samojedny”, „samowtór”, „samowtóry”, „samotrzeć”, „samotrzeci”, „samoczwart”, „samoczwarty”, „samodwunast” itd. mające znaczenie "sam z tyloma, że razem jest tylu, na ile wskazuje człon liczebnikowy wyrazu'. Jest to konstrukcja o tyle 
ciekawa, że zdaje się pokazywać pewną wewnętrzną sprzeczność - z jednej strony wskazuje bowiem na potrzebę indywidualizacji, wyodrębnienia (sam), z drugiej zaś świadczy o świadomości bycia częścią grupy. Trudno taki fenomen przyporządkować do świadectw wschodniego bądź zachodniego systemu myślenia. Taka konstrukcja nie przystaje do żadnego z nich.

Jako inne poświadczenie językowe Nisbett przywołuje teksty reklamowe amerykańskie i koreańskie. Otóż okazuje się, że reklamy amerykańskie kładą akcent na indywidualne korzyści i preferencje adresatów („Wybierz własną drogę, zostaw tłum za sobą”, „Przyjemność, dzięki której poczujesz, że żyjesz”, „Save your mouth for Mentos”, „I'm lovin'it”, „Dare for more”, „Ask for more”, „Be free" itp. itd.), reklamy koreańskie zaś na ogół podkreślają aspekt zbiorowości (,Wiemy, jak zbliżyć ludzi”, „Przynosimy wieści o prawdziwym partnerstwie w biznesie" itd.) $)^{3}$. Ponadto przeprowadzone eksperymenty wykazały, że na Amerykanów skuteczniej oddziaływały reklamy podkreślające wartości indywidualistyczne, natomiast na Koreańczyków - reklamy o charakterze kolektywistycznym (Nisbett 2011:61).

Jeśli chodzi o polskie reklamy, to ich formy gramatycznoleksykalne są zróżnicowane (np. „ty” - 2. os. lp. trybu orzekającego, 2. os. lp. trybu rozkazującego, „wy" - 2. os. lm. trybu orzekającego, ,ja" - 1. os. lp. trybu orzekającego, „my” - 1. os. lm. trybu orzekającego, formy bezosobowe - „nikt”, „wszyscy”) i dla kategorycznych stwierdzeń potrzeba by dokładnych badań statystycznych ${ }^{4}$. Niemniej w kategoriach indywidualność versus zbiorowość szacunkowo można wnioskować o przewadze komunikatów podkreślających indywidualność potrzeb i korzyści (np. „Budujesz - Remontujesz - Urządzasz” Castorama, „Możesz więcej” - ERA, „Podaj to, co najlepsze” - Tchibo, „Tak jak lubisz” - Pizza Hut, „Ta kawa budzi mnie” - Woseba ${ }^{5}$ ). Teksty reklamowe odwołujące się do zbiorowości są zdecydowanie rzadsze (np. „Ten smak was nakręci” - Fanta, „Łączcie się długo i szczęśliwie” - Plus GSM, „Odkryjmy lepszy świat” - Philips ${ }^{6}$ ). Pojawiają się też oczywiście hasła, które wykorzystują tak zwane wielkie kwantyfikatory i określenia o charakterze generycznym (np. „Nikt się nie oprze wspaniałym, miodowym kółeczkom Nestle Cheerios”, „Napój wszystkich generacji” - Polococta, „Kto zje, ten zrozumie” - Rama Creme Bonjour, „Zapach wyłącznie dla mężczyzny” - STR8, „Doznanie tylko dla kobiet z brązowymi włosami” - Timotei). Chociaż i tak wydaje się, że najwięcej jest przesłań neutralnych pod tym względem, a skupiających uwagę na samym produkcie czy na usłudze (np. „Codziennie niskie ceny” - Biedronka, „Raz na długi czas” - Dekoral, „Działa do ośmiu razy dłużej” - Duracell, „Czekoladowa

\footnotetext{
${ }^{3}$ Przykłady sloganów reklamowych podano za Nisbettem, dla wyrazistości do przykładów amerykańskich dodano jeszcze kilka tekstów w języku angielskim.

${ }^{4}$ Przykłady sloganów reklamowych czerpano przede wszystkim z artykułu Danuty Grolewskiej i Joanny Rachockiej (Grolewska, Rachocka 2005).

${ }^{5}$ Inne przykłady: „Dostajesz więcej za mniej” - Telekomunikacja Polska, „Zażywaj młodości” - Biosteron, „Zdziwisz się, że świeżość tak długo trwa” - Lenor, „Kochaj życie” - Tymbark, „Bądź piękna” - Soraya.

${ }^{6}$ Inne przykłady: „Naszym sekretem jest ciasto” - Telepizza, „Zbliża ludzi” - Western Union.
} 
pycha” - Chocapic, „Zdrowo zakręcony” - Fortuna, „Witalność na każdy dzień” Geriavit Pharmaton ${ }^{7}$ ).

A zatem w tej kwestii polszczyzna nie wydaje się wykazywać żadnych wyraźnych inklinacji, zwłaszcza że nie ma potwierdzeń naukowych co do tego, jaki typ komunikatu preferują polscy odbiorcy. Jeśliby trzeba jednak określić, do kogo jesteśmy bardziej podobni, to wzorzec myślenia zachodniego może się wydawać nieco bliższy, aczkolwiek może to też wynikać z tego, że obecnie kultura angloamerykańska jest $\mathrm{w}$ dużej mierze narzucana Polakom m.in. przez koncerny reklamowe, które wprowadzają na polski rynek część reklam „zachodnich” dodawszy tylko do nich polski przekład tekstu.

W innym miejscu autor zauważa, że na Zachodzie ludzie uczą swoje dzieci roli nadawcy, na którym spoczywa odpowiedzialność za precyzję wypowiedzi i zrozumiałość komunikatu. W związku z tym w społeczeństwach tych panuje przeświadczenie, że kłopoty w komunikacji i porozumieniu są winą mówiącego. W Azji Wschodniej natomiast dzieci są uczone roli odbiorcy, co oznacza, że odpowiedzialność za skuteczność komunikacyjną i zrozumienie spada na słuchacza (Nisbett 2011:57).

Gdy pomyśleć o tym aspekcie w odniesieniu do polskiej rzeczywistości, to nie sposób oprzeć się przywołaniu czysto szkolnego przykładu - „dlaczego dziecko nie rozumie lekcji”. Zgodnie ze stereotypami społecznymi winą za to na ogół jest obarczany sam uczeń (to uczeń źle zrozumiał lub nie zrozumiał, a nie nauczyciel źle wyjaśnił, dlatego też co troskliwsi czy zamożniejsi rodzice posyłają dzieci na korepetycje). Wprawdzie polski system edukacji jest obecnie reformowany i w zakresie komunikacji i relacji nauczyciel-uczeń również następują zmiany, niemniej w codziennym funkcjonowaniu polskiej szkoły siła stereotypu jeszcze wyraźnie daje o sobie znać.

Ciekawym wątkiem w wywodzie Nisbetta jest także kwestia konstrukcji logiczno-gramatycznej przysłów. Autor stwierdza, że sentencje oparte na przeciwstawieniu i zawierające w sobie sprzeczność (typu: „Strzeż się przyjaciół, nie wrogów”, „Człowiek jest twardszy od głazu, ale delikatniejszy od róży”) są bardziej typowe dla przysłów chińskich niż dla amerykańskich, wśród których dominują proste stwierdzenia (typu: „Lepszy rydz niż nic”, „Jeden kij nie czyni płotu") (Nisbett 2011:128-129). Ponadto badania polegające na ocenie różnych przysłów wykazały, że chińscy studenci lubią przysłowia zawierające sprzeczności, amerykańscy zaś te, w których sprzeczności nie występują.

Analiza polskich przysłów wymagałaby osobnego studium. Mamy bowiem zarówno jeden typ sentencji (np. „Apetyt rośnie w miarę jedzenia”, „Na bezrybiu i rak ryba”, „Chcesz stracić przyjaciela, pożycz mu pieniędzy”, „Głupstwa bogatego uchodzą za mądrość”), jak i drugi (np. „Baba z wozu, koniom lżej”, „Gdzie dwóch się bije, tam trzeci korzysta”, „Zgoda buduje, niezgoda rujnuje”, „Niedaleko pada jabłko od jabłoni”). Pobieżny przegląd polskich słowników

\footnotetext{
${ }^{7}$ Inne przykłady: „Mroźna świeżość oddechu na długi czas” - Winterfresh, „Bezwzględny dla brudu, łagodny dla powierzchni" - Cif, „Trwałe piękno drewna” - Sadolin, „To więcej niż oszczędność” - Link4, „Dębowe. Długo warzone”, „Tyskie ma 375 lat”, „Pyszne picie, fajne życie” - napój Jupik, „Rexona pachnie nagrodami”, „Smaczny zapas sił" - Lu Petitki, „3BIT obsesja trzeciego stopnia”, „Aby ruch nie sprawiał bólu" - Artresan.
} 
przysłów wskazywałby na liczebną przewagę przysłów prostych i „logicznych”. Jednak który typ rzeczywiście przeważa i który jest preferowany przez Polaków na pewno warto by dokładnie zbadać, nie tylko ze względu na konfrontację $\mathrm{z}$ teorią Nisbetta.

Kolejnym aspektem językowym poświadczającym różnice w myśleniu jest kwestia werbalizacji sprawczości. Nisbett zauważa, że w świadomości mieszkańców świata zachodniego działanie wykonuje określony podmiot (JA), natomiast dla mieszkańców Dalekiego Wschodu działanie jest podejmowane w harmonii z innymi albo po prostu wynika $\mathrm{z}$ interakcji podmiotu (JA) z siłami pola $\mathrm{i}$ nie ma w tym wypadku mowy o spersonalizowanej sprawczości czy skonkretyzowanym źródle działania. Język zdaniem badacza odzwierciedla owo odmienne podejście do sprawczości. Większość języków zachodnich, jak wskazuje, wyraża tę sprawczość eksplicytnie na poziomie gramatycznym i leksykalnym („On to upuścił”), języki wschodnie zaś raczej tej sprawczości eksplicytnie nie wyrażają („To mu upadło” albo po prostu „Upadło”) (Nisbett 2011:119).

W tej kwestii polszczyzna okazuje się bardzo elastyczna: zasadniczo nie jesteśmy językowo zobowiązani do wyrażania sprawczości, do nadawcy należy decyzja, czy sprawczość wyrazi w sposób bezpośredni („Wylała herbatę”, „Studenci nakręcili film”) czy pośredni („Wylała jej się herbata”, „Film został nakręcony przez studentów"), czy może w ogóle tę sprawczość przemilczy (,Wylała się herbata”, „Nakręcono film”) .

Jeśli zaś chodzi o opanowywanie języka na początkowym etapie rozwoju ontogenetycznego, to jak wskazuje autor, odwołując się do badań psychologów rozwojowych, dzieci azjatyckie (uczone przez rodziców, co można zrobić z danym obiektem) szybciej niż dzieci amerykańskie opanowują znajomość czasowników, natomiast dzieci amerykańskie, które od samego początku są uczone wyodrębniania i nazywania obiektów, siłą rzeczy w pierwszej kolejności i z łatwością opanowują rzeczowniki, których zresztą mają w systemie językowym więcej niż czasowników (Nisbett 2011:112-114). Skutkuje to według autora percepcyjną orientacją na obiekty i kategorie w wypadku ludzi ze świata amerykańsko-zachodnioeuropejskiego oraz orientacją na czynności i relacje $\mathrm{w}$ wypadku ludzi ze świata wschodnioazjatyckiego, jak również rzeczownikowych charakterem języków zachodnich i czasownikowym charakterem języków wschodnich. Co do polskich dzieci, to nauka języka w początkowym etapie rozwojowym powiela model zachodni i rzeczywiście polega przede wszystkim na opanowywaniu rzeczowników, co uwidacznia się m.in. w książeczkach dla dzieci typu „moje pierwsze słowa”, w których ilustracje przedstawiają przede wszystkim lalki, misie, samochody, ptaki, kotki, pieski itp., znacznie rzadziej zaś przedstawiają kąpanie się, jedzenie, mycie, spanie itd.

\footnotetext{
${ }^{8}$ Zdarzają się nawet wypadki tego rodzaju wypowiedzeń, kiedy nie można wskazać nie tylko sprawcy działania, lecz nawet podmiotu - „Grzmi”, „Błyska się”.
} 


\section{Analizy leksykalne a zróżnicowanie systemów myślenia}

Rozpatrując w kontekście swoich tez leksykę jako system, Nisbett za kluczową kwestię poświadczającą różnice mentalności dalekowschodniej i amerykańskozachodnioeuropejskiej uważa kwestię werbalności i nominalności języka (i przy okazji w dalszej kolejności - pozycji czasowników i rzeczowników w wypowiedzeniu). Dodatkowo wspomina też kwestię wieloznaczności wyrazów z tych dwóch podstawowych grup gramatycznych i sposobów generycznego użycia leksemów rzeczownikowych. Jednemu z rozdziałów autor daje znamienny tytuł „Świat rzeczowników i świat czasowników”.

Naprawdę jednak Nisbett nie analizuje całościowo leksyki - nie znajdziemy w tej monografii wymiernych, statystycznych badań nad systemem, nie ma w niej podanych np. proporcji czasowników do rzeczowników w poszczególnych, wzmiankowanych językach. $Z$ tego powodu trudno jest się odnieść do przedstawianych twierdzeń i trudno też zestawiać je $\mathrm{z}$ analizami dotyczącymi polszczyzny. Niemniej warto przyjrzeć się niektórym statystykom i zastanowić się, o czym mogłyby one świadczyć.

Okazuje się, że trudno w jednoznaczny sposób mówić o werbalnym lub nominalnym charakterze polskiego słownictwa. Jeżeli bowiem sięgniemy do badań prowadzonych w tym zakresie, to okaże się, że wiele w tej kwestii zależy od sposobu ujęcia materiału.

Pierwsze istotne badania dotyczące struktury gramatycznej ogółu polskiego zasobu leksykalnego opublikował w roku 1988 Zygmunt Saloni, korzystając z materiału zawartego w „Słowniku języka polskiego” publikowanego w latach 1958-69 pod redakcją Witolda Doroszewskiego (Saloni 1988). Podstawę analizy stanowiło zatem około 125 tys. jednostek wyrazowych języka polskiego (na użytek dalszych analiz określimy je jako próbę I). Wyniki, jakie uzyskano, przedstawiają się następująco (tabela 2. oraz rysunek 1.):

Tabela 2. Struktura gramatyczna polskiej leksyki (całościowo) ${ }^{9}$.

\begin{tabular}{|l|c|}
\hline Części mowy & $\begin{array}{c}\text { Udzial } \\
\text { procentowy } \\
\text { w ogóle leksyki }\end{array}$ \\
\hline rzeczowniki & $55,0 \%$ \\
\hline przymiotniki & $19,6 \%$ \\
\hline czasowniki & $19,4 \%$ \\
\hline przysłówki & $4,0 \%$ \\
\hline
\end{tabular}

${ }^{9}$ Zestawienie procentowe podano za Andrzejem Markowskim (Markowski 1992a:70). 
Rys. 1. Struktura gramatyczna polskiej leksyki (całościowo).

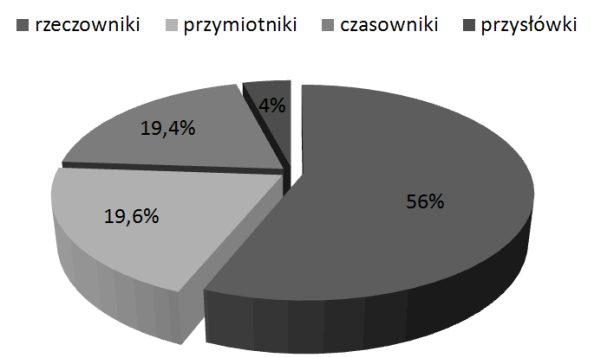

Analogicznych obliczeń dokonał niedługo potem Andrzej Markowski, autor wydanego w roku 1992 tzw. „Słownika wyrazów wspólnych” (Markowski 1992b). Tym razem jednak podstawę analizy stanowiło słownictwo wspólnoodmianowe (w liczbie ok. 6100 jednostek wyrazowych), czyli wyrazy neutralne pod względem stylistycznym i emocjonalnym, znane bez mała wszystkim użytkownikom języka i używane przez nich na co dzień niemal w każdej sytuacji (na użytek dalszych analiz określimy je jako próbę II) (Markowski 1992a:70). Struktura gramatyczna słownictwa w tym wypadku przedstawia się, jak następuje (tabela 3. oraz rysunek 2.):

Tabela 3. Struktura gramatyczna polskiej leksyki wspólnoodmianowej.

\begin{tabular}{|l|c|}
\hline Części mowy & $\begin{array}{c}\text { Udział procentowy } \\
\text { w leksyce } \\
\text { wspólnoodmianowej }\end{array}$ \\
\hline rzeczowniki & $42,6 \%$ \\
\hline przymiotniki & $11,7 \%$ \\
\hline czasowniki & $36,0 \%$ \\
\hline przysłówki & $5,4 \%$ \\
\hline
\end{tabular}

Rys. 2. Struktura gramatyczna polskiej leksyki wspólnoodmianowej.

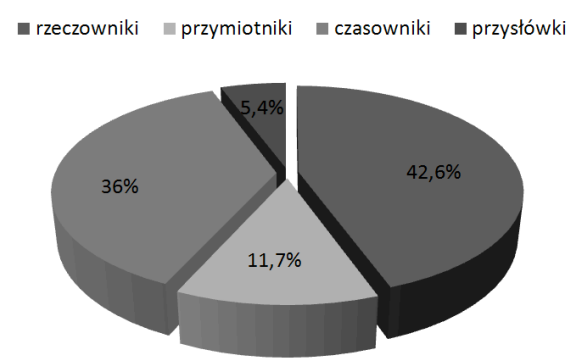

Jeszcze inaczej z kolei przedstawia się sytuacja, jeśli wziąć pod uwagę słownictwo potoczne, nacechowane stylistycznie i emocjonalnie (na użytek dalszych analiz określimy je jako próbę III), które badała Danuta Buttler (Buttler 1977a, Buttler 1977b, Buttler, Markowski 1988) (tabela 4. oraz rysunek 3.): 
Ewa Rudnicka: Problematyka polskiej leksyki ogólnej w świetle...

Tabela 4. Struktura gramatyczna polskiej leksyki potocznej ${ }^{10}$.

\begin{tabular}{|l|c|}
\hline Części mowy & $\begin{array}{c}\text { Udzial } \\
\text { procentowy } \\
\text { w leksyce } \\
\text { potocznej }\end{array}$ \\
\hline rzeczowniki & $75 \%$ \\
\hline przymiotniki & $5 \%$ \\
\hline czasowniki & $20 \%$ \\
\hline
\end{tabular}

Rys. 3. Struktura gramatyczna polskiej leksyki potocznej.

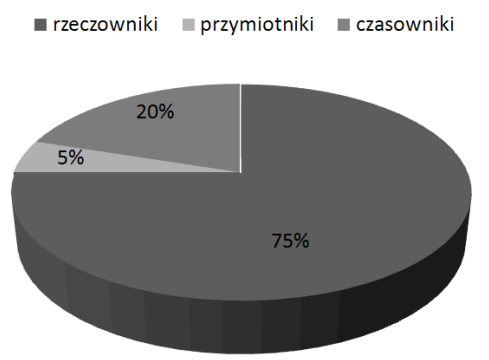

Po zestawieniu wyników uzyskanych w trzech omawianych próbach uzyskuje się następujący obraz (rysunek 4.):

Rys. 4. Struktura gramatyczna leksyki w różnych odmianach polszczyzny.

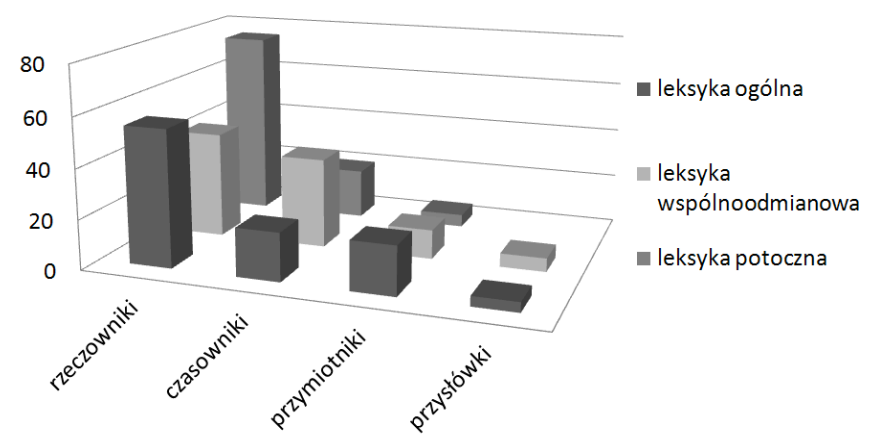

Okazuje się zatem, że w zależności od doboru materiału badawczego otrzymujemy różne wyniki - słownictwo wspólnoodmianowe stanowi próbę dużo bardziej wyważoną niż dwie pozostałe (próby I i III), natomiast słownictwo całkowite i słownictwo potoczne mają wyraźnie nominalny charakter. Andrzej Markowski, który zestawił ze sobą te dane, twierdził na ich podstawie, że słownictwo wspólnoodmianowe w większym stopniu mówi o dzianiu się czegoś, odnosi się raczej do czynności niż do nazywania elementów rzeczywistości, a

\footnotetext{
${ }^{10}$ Dane liczbowe przytoczono za Andrzejem Markowskim (Markowski 1992a:70).
} 
powodów silnej nominalizacji materiału zawartego w „Słowniku języka polskiego" upatrywał w tym, że w słowniku odnotowano wiele rzeczowników pochodzących z odmian specjalnych.

W związku z tym wydaje się, że chcąc wnioskować o nominalności vel werbalności polszczyzny jako takiej, nie można opierać się wyłącznie na jednym z powyższych badań, z kolei interpretacja tak rozbieżnych wyników sprawia trudność. Zauważmy jednak, że mimo wszystko, niezależnie od badania, przewagę w leksyce mają rzeczowniki, można by więc stwierdzić, że polszczyzna jest znominalizowana, aczkolwiek wziąwszy pod uwagę istotność frekwencyjną każdej z prób ${ }^{11}$ należałoby dookreślić siłę tego zjawiska. Sądząc po proporcjach zwłaszcza w próbach II i I, wypadałoby stwierdzić, że stopień nominalizacji raczej nie jest duży. Żeby jednak móc z większą pewnością coś takiego powiedzieć, należałoby dysponować odpowiednimi danymi odnoszącymi się chociażby do języka angielskiego i - powiedzmy - chińskiego ${ }^{12}$.

O nominalności angielszczyzny i innych języków zachodnioeuropejskich, a werbalności języków wschodnioazjatyckich świadczy zdaniem Nisbetta także pozycja w zdaniu rzeczownikowego podmiotu i czasownikowego orzeczenia. Autor zwraca uwagę na to, że w chińskim, japońskim i koreańskim czasowniki znajdują się zwykle na początku lub na końcu zdania, czyli w miejscach szybko zauważalnych. Języki zachodnie natomiast wymuszają jego zdaniem skupienie uwagi na obiektach, gdyż szczególne miejsce w zdaniu zajmuje podmiot, czasowniki zaś są częściej umiejscowione gdzieś w środku zdania. Zatem w językach wschodnioazjatyckich czasowniki są bardziej wyeksponowane niż w języku angielskim i wielu innych językach europejskich, co w mniemaniu autora wskazuje na werbalność języków wschodnioazjatyckich i nominalność języków zachodnich (Nisbett 2011:113-114).

Znów trudno odnieść takie stwierdzenia do polszczyzny, która w przeciwieństwie do analitycznych języków zachodnich i dalekowschodnich jako język o silnie rozbudowanym systemie fleksyjnym rządzi się zupełnie innymi prawami i w której szyk wyrazów w zdaniu jest swobodny, a jego rola znaczeniotwórcza jest minimalna. Pozycja czasownika w zdaniu jest rzeczywiście ważna, czasownik konstytuuje zdanie, określa relacje między pozostałymi częściami wypowiedzenia i narzuca ich formę gramatyczną, a przy tym nie wymaga werbalizacji podmiotu. W polskich gramatykach przyjmuje się zasadniczo, że najważniejsze $\mathrm{w}$ zdaniu jest orzeczenie, podmiot - mimo że wchodzi z orzeczeniem w związek zgody - nie jest jednak konstytuującym elementem zdania. Można by więc sądzić, że w kwestii pozycji w zdaniu czasownika (orzeczenia) / rzeczownika (podmiotu) powyższe stwierdzenia wskazywałaby na prowschodnie inklinacje polszczyzny, gdyby nie to, że do

\footnotetext{
${ }^{11} \mathrm{~W}$ całym zbiorze leksykalnym mamy nie tylko rzadko stosowaną $\mathrm{w}$ codziennym porozumiewaniu się terminologię, lecz także dużo derywatów słowotwórczych, których użycie w komunikacji codziennej również nie jest częste.

${ }^{12}$ Chociaż trzeba pamiętać, że przygotowanie tego rodzaju statystyk dla języka chińskiego byłoby zadaniem trudnym z tego względu, że formalnie w chińszczyźnie brak rozróżnienia między częściami mowy - na podstawie postaci wyrazu nie można określić jego rodzaju, liczby, przypadka, czasu itd., gdyż kategorie te wynikają z kontekstu słownego i szyku wyrazów w zdaniu, a w razie potrzeby mogą być sygnalizowane słowami posiłkowymi (Mizerski 2000:262).
} 
większości języków zachodnich też by można odnieść dużą część przedstawionych powyżej stwierdzeń.

Druga istotna kwestia wchodząca w obręb zagadnień leksykalnych, którą omawia Nisbett, dotyczy wieloznaczności słów. W językach wschodnioazjatyckich sens wypowiedzi w bardzo dużym stopniu zależy od kontekstu, ponieważ słowa mają zazwyczaj wiele znaczeń. Słowa w języku angielskim - jak wskazuje Nisbett - są raczej jednoznaczne, a wypowiedzi są zazwyczaj budowane w taki sposób, aby zrozumienie ich nie wymagało szerszego kontekstu (Nisbett 2011:118).

By sprawdzić rzecz na polskim materiale językowym, wykonano analizy statystyczne na dwóch próbach materiału. Próbę pierwszą stanowiło (podobnie jak w wypadku wcześniejszych danych statystycznych) słownictwo zaczerpnięte ze słownika ogólnego języka polskiego (w tym wypadku były to wszystkie hasła na literę $\mathrm{K}$ zawarte $\mathrm{W}$ „Uniwersalnym słowniku języka polskiego" pod red. Stanisława Dubisza), drugą zaś leksyka wspólnoodmianowa zawarta w „Słowniku wyrazów wspólnych" Andrzeja Markowskiego ${ }^{13}$. Okazało się przy okazji, że wielkość prób jest mniej więcej porównywalna (próba I - 6626, próba II - 5603). W próbie pierwszej polisemy stanowiły $37,97 \%$, natomiast $\mathrm{w}$ próbie drugiej zaledwie $8,89 \%$. Różnica wyników jest tyleż zaskakująca ${ }^{14}$, co trudno interpretowalna. Ponownie stajemy bowiem przed problemem, jaki materiał badawczy powinien stanowić podstawę do wnioskowania o charakterze języka jako takiego. (A niezależnie od tego należałoby jeszcze przedstawiane badania przeprowadzić na większych próbach).

Dla pełniejszego obrazu dokonano również sprawdzenia struktury gramatycznej wyrazów wieloznacznych: przeliczono w poszczególnych próbach, ile wśród wyodrębnionych polisemów występuje rzeczowników, czasowników, przymiotników itd. Wyniki uzyskane w próbie I przedstawiają się następująco (tabela 5. oraz rysunek 5.):

Tabela 5. Struktura gramatyczna słownictwa polisemicznego w polskiej leksyce ogólnej (litera K).

\begin{tabular}{|l|c|}
\hline Części mowy & $\begin{array}{c}\text { Udział procentowy } \\
\text { w grupie } \\
\text { polisemów }\end{array}$ \\
\hline rzeczowniki & $59,8 \%$ \\
\hline czasowniki & $10,7 \%$ \\
\hline przymiotniki & $24,4 \%$ \\
\hline przysłówki & $5,0 \%$ \\
\hline
\end{tabular}

\footnotetext{
${ }^{13} \mathrm{Na}$ potrzeby tych analiz konieczne było nieco odmienne od autorskiego potraktowanie haseł i danych liczbowych, gdyż autor jako hasło przyjmował jednostkę leksykalną, na użytek tego badania zaś konieczne było przyjęcie, że hasłem jest wyraz (tradycyjne hasło słownikowe), w przeciwnym razie nie można by było mówić o polisemii.

${ }^{14}$ Można by się raczej spodziewać, że to w zbiorze wyrazów podstawowych, gdzie nie ma terminologii, udział jednostek polisemicznych będzie większy. Choć jeśli wziąć pod uwagę, że leksyka wspólnoodmianowa nie obejmuje również ekspresywizmów, w których wypadku wieloznaczność jest dość częsta, to wyniki aż tak bardzo dziwić nie będą.
} 


\begin{tabular}{|l|r|}
\hline inne & $0,08 \%$ \\
\hline
\end{tabular}

Rys. 5. Struktura gramatyczna słownictwa polisemicznego w polskiej leksyce ogólnej (litera K).

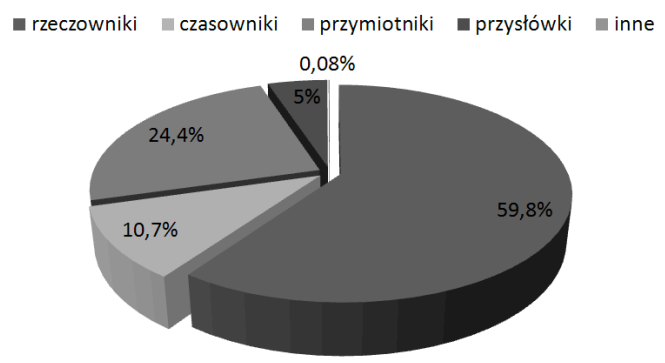

Wyniki uzyskane w próbie II ilustruje kolejne zestawienie (tabela 6. oraz rysunek 6.):

Tabela 6. Struktura gramatyczna słownictwa polisemicznego w polskiej wspólnoodmianowej.

\begin{tabular}{|l|c|}
\hline Części mowy & $\begin{array}{c}\text { Udzial procentowy } \\
\text { w grupie } \\
\text { polisemów }\end{array}$ \\
\hline rzeczowniki & $40,96 \%$ \\
\hline czasowniki & $43,98 \%$ \\
\hline przymiotniki & $14,86 \%$ \\
\hline
\end{tabular}

Rys. 6. Struktura gramatyczna słownictwa polisemicznego w polskiej wspólnoodmianowej.

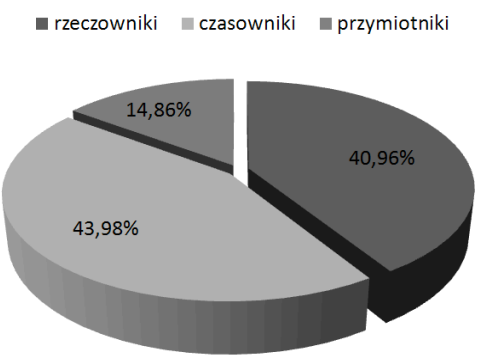

Porównawczo natomiast można rzecz ująć następująco (rysunek 7.): 
Rys. 7. Struktura gramatyczna słownictwa polisemicznego w różnych odmianach polszczyzny.

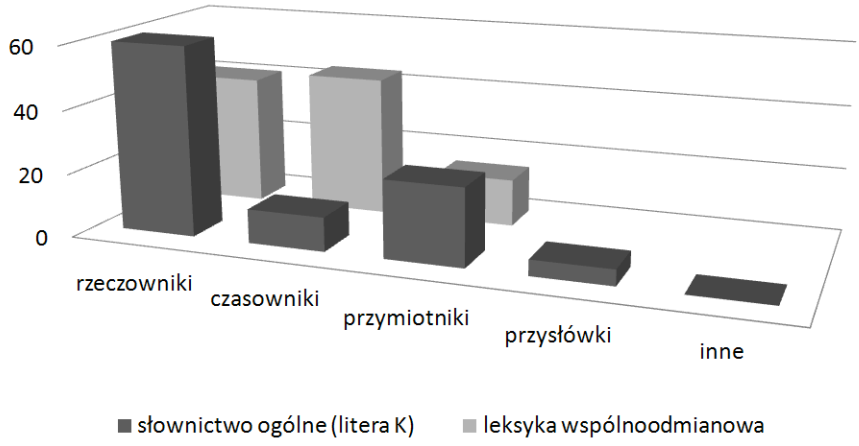

Jak widać, pod wieloma względami leksyka ogólna (tj. brana pod uwagę w całości) różni się od leksyki wspólnoodminowej, czyli od tego, co stanowi swego rodzaju jądro leksykalne języka. Nie tylko udział procentowy polisemów w poszczególnych grupach jest mocno zróżnicowany, lecz także struktura gramatyczna tej grupy wyrazowej jest zupełnie inna w każdej z prób. Zatem mówiąc o języku polskim ogólnie, trzeba znów wyniki w jakiś sposób standaryzować, uśredniać. Summa summarum wydaje się, że polszczyznę można określić jako język raczej o niedużym nasyceniu polisemami.

Z poruszanych przez Nisbetta kwestii leksykalnych pozostaje jeszcze do omówienia użycie rzeczowników w funkcji generycznej. Badacz zwraca uwagę na to, że w wypadku angielszczyzny i innych języków zachodnioeuropejskich rzeczowniki w użyciu generycznym, o niekreślonej desygnacji i rzeczowniki w znaczeniu skonkretyzowanym wymagają zastosowania odmiennych rodzajników. Forma gramatyczna (np. „a dog”, „the dog”, „the dogs”, „dogs”) pozwala odbiorcy na jednoznaczną interpretację znaczenia wyrazu. Dla odmiany w języku chińskim i innych językach Wschodniej Azji tego rodzaju wskazówek odbiorca musi szukać w kontekście i konsytuacji.

Pod tym względem polszczyzna odbiega od wzorców zachodnich: każdemu ze zdań „Wiewiórka je orzechy”, „Wiewiórki jedzą orzechy” można przypisać zarówno desygnację jednostkową, jak i nieokreśloną desygnację generyczną, natomiast o tym, która jest w danym wypadku właściwa, decyduje kontekst, w jakim się zdanie pojawia.

\section{Podsumowanie}

Aby skrótowo, a zarazem obrazowo przedstawić konkluzje powyższych rozważań, można posłużyć się diagramem, na którym szarym tłem wyróżniono aspekty leksykalne (najistotniejsze w tym wywodzie), a literami $\mathrm{Z} \mathrm{i} \mathrm{W}$ oznaczono modelowe cechy myślenia zachodniego (amerykańsko-zachodnioeuropejskiego) i wschodniego (wschodnioazjatyckiego): 
Rys. 8. Językowe poświadczenie wybranych cech polskiej umysłowości w odniesieniu do wzorców amerykańsko-zachodnich i dalekowschodnich.

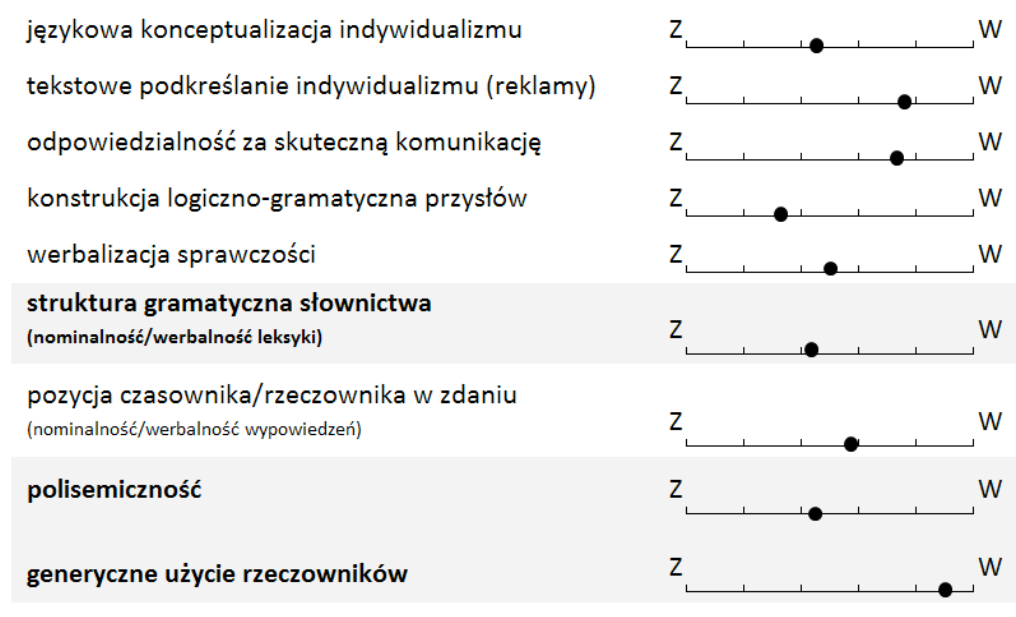

A zatem, odwołując się do diagramu, na pytanie badawcze postawione na początku niniejszego tekstu należy odpowiedzieć negatywnie - na podstawie analiz językowych dotyczących poziomu leksykalnego, jak również innych wybranych cech gramatycznych i pragmatycznych polszczyzny nie można powiedzieć o polskiej wspólnocie komunikacyjnej, że w swoim myśleniu jest bliższa jednemu lub drugiemu modelowi myślenia, że wykazuje jakieś określone „pokrewieństwo mentalne”. Wydaje się, że polska leksyka w swoim charakterze nie jest zbliżona ani do modelu wschodniego, ani do modelu zachodniego (chociaż $\mathrm{w}$ tej kwestii potrzebne są jeszcze dalsze badania, ze względu na niejednolitość wyników badań przeprowadzonych dotychczas). Wydaje się także, iż inne cechy polszczyzny również nie pozwalają określić typu polskiej umysłowości. „Wydaje się”, ponieważ trzeba jednak szczerze przyznać, że właściwie żaden $\mathrm{z}$ argumentów, które przecież starano się dobrać i przedstawić logicznie i racjonalnie, nie przemawia dość silnie i w sposób przekonujący. Aby rzetelnie móc coś stwierdzić, należałoby rozszerzyć skalę badań na pola pozajęzykowe (gdyż temat niewątpliwie jest godzien uwagi), a ponadto należałoby właściwie przeprowadzić również badania komparatywne, porównując język polski choćby z angielskim i chińskim.

Oczywiście w badaniach nad kulturowymi uwarunkowaniami procesów myślenia nie ulega kwestii istotność analiz językowych (a w tym i analiz leksyki), choć trzeba do tego rodzaju dowodów językowych podchodzić z odpowiednią dozą krytycyzmu, ponieważ, jak wiadomo, ludzkie myślenie nie jest li tylko myśleniem werbalnym, równie ważną rolę w ludzkim poznaniu odgrywa myślenie niewerbalne. Należy więc sobie zdawać sprawę z ograniczonej „siły” tych dowodów i w tego rodzaju dociekaniach sięgać, jak wspomniano, także po wyniki innych badań - psychologicznych, antropologicznych, etnograficznych, socjologicznych, historycznych etc.

Tymczasem kwestia polskiego modelu myślenia i jego językowych przejawów zdaje się zbyt złożona i uwarunkowana zbyt wieloma czynnikami, żeby można ją 
Ewa Rudnicka: Problematyka polskiej leksyki ogólnej w świetle...

było badać w tak uproszczony siłą rzeczy sposób. Ale być może wynika to z tego, że w sposobie myślenia autorka niniejszych słów sama miast sięgać po zachodnie wzorce wywodu naukowego grzeszy mentalnością prowschodnią i widzi problemy tam, gdzie być może ich nie ma. 


\section{Bibliografia}

Buttler, D. 1977a. Polskie słownictwo potoczne. I. Cechy fonetyczne i fleksyjne leksemów. II. Słowotwórstwo. W: Poradnik Językowy, z. 3, s. 89-98

Buttler, D. 1977b. Polskie słownictwo potoczne. III. Charakterystyka leksykalnosemantyczna zasobu słownikowego. W: Poradnik Językowy, z. 4, s. 153-163

Buttler, D., Markowski, A. 1988. Słownictwo wspólnoodmianowe, książkowe i potoczne współczesnej polszczyzny. W: Anusiewicz, J., Bartmiński, J. (red.). 1988. Język a kultura, t. 1. Wrocław, s. 179-205

Dubisz, S. 2003: Uniwersalny słownik języka polskiego, t. 2. Warszawa: PWN

Głowiński, M. (red.) 1980. Język i społeczeństwo, przekł. J. Arnold, K. Biskupski, K. Falicka, J. Faryno, M. Łukasiewicz. Warszawa: Czytelnik

Grolewska, D., Rachocka, J. 2005. Slogan reklamowy, czyli jak skutecznie zachęcać do zakupów, http://www.swiatmarketingu.pl/index.php?rodzaj=01\&id_numer=312286

Markowski, A. 1992a. Leksyka wspólna różnym odmianom polszczyzny, t. I. Wrocław: Wydawnictwo „Wiedza o kulturze”

Markowski, A. 1992b. Leksyka wspólna różnym odmianom polszczyzny, t. II. Dodatki. Wrocław: Wydawnictwo „Wiedza o kulturze”

Mizerski, W. (red.). 2000: Język polski. Encyklopedia w tabelach. Warszawa: Wydawnictwo Adamantan

Nisbett, R.E. 2009. Geografia myślenia. Dlaczego ludzie Wschodu i Zachodu myślą inaczej, przekł. E. Wojtych. Sopot: Wydawnictwo „Smak Słowa”

Saloni, Z. 1988. Struktura gramatyczna słownictwa zawartego w „Słowniku języka polskiego PAN" pod red. W. Doroszewskiego - zestawienie liczbowe. W: Saloni, Z. (red.). 1988. Studia z polskiej leksykografii współczesnej, t. 1. Wrocław: Zakład Narodowy im. Ossolińskich, s. 149-161 